\title{
The Role of Customer Satisfaction in Mediating the Influence of Brand Personality and Service Quality on the Loyalty of Beachwalk Shopping Center Customers
}

\author{
Nafira Fitri ${ }^{1 *}$ Ni Wayan Sri Suprapti ${ }^{2}$ \\ 1. Faculty of Economics and Business, Udayana University, Bali, Indonesia \\ 2. Faculty of Economics and Business, Udayana University, Bali, Indonesia \\ * E-mail of the corresponding author : fyrana02@gmail.com
}

\begin{abstract}
In 2018 and 2019, there was an increase in the number of shopping centers in Bali, which led to the tight competition in the industry. The movement of customers from one shopping center to other shopping centers indicate that the loyalty of customers can be categorized as low. This challenges business practitioners in their attempt to maintain and win the competition within the industry. This research focuses on the role of customer satisfaction, brand personality and service quality in developing the loyalty of Beachwalk Shopping Center customers. This research is categorized as an associative quantitative study and was conducted in Badung Regency, Bali. The data consists of 218 Beachwalk Shopping Center visitors, collected by distributing questionnaires which include open-ended and close-ended questions. The validity and reliability of these questions have also been verified. The analysis technique used is the Structural Equation Modelling (SEM) and the analysis tool utilized is the SmartPLS 3.0. The research results revealed that customer satisfaction and brand personality have a positive and significant influence on customer loyalty, but service quality does not have a significant influence on customer loyalty. The results also showed that customer satisfaction is capable of mediating the influence of brand personality and service quality on the loyalty of Beachwalk Shopping Center customers. Another result of this study is that there is no significant difference between the satisfaction and loyalty of local and foreign customers, indicated by both having equally high values of customer satisfaction and customer loyalty.
\end{abstract}

Keywords: brand personality, service quality, customer satisfaction and customer loyalty

DOI: $10.7176 / \mathrm{EJBM} / 12-20-11$

Publication date:July $31^{\text {st }} 2020$

\section{Introduction}

Shopping centers are currently the most popular recreation area and provide large business opportunities in Bali. The results of BI's Retail Trade Index Survey in the $4^{\text {th }}$ quartile of 2018 showed that the retail shopping centers in Bali has a fairly large occupancy rate at 85.91 percent of the total 237,009 square meters prepared by 11 shopping centers in Kuta, Nusa Dua, Seminyak, Renon and Benoa (Antara News, 2018). In July 2019, Bali's IPR was recorded at 137.5 or higher than the average in the second quartile of 2019 which was 136.5 (Berita Bali, 2019).

Every year the number of shopping centers in Bali increases and this was followed by the fierce competition in attracting visitors. The movement of customers from one shopping center to another often occurs. This indicates that the loyalty of visitors is low. The tight competition is also felt by Beachwalk Shopping Center Bali, even though it is the number 1 shopping center in Bali based on Trip Advisor and is the market leader of shopping centers in Bali. Subsequently, the management must develop a strategy to provide more value to visitors and be able to build the loyalty of their visitors.

In developing loyalty, customer satisfaction is important (Schiffman \& Kanuk, 2007). Customer satisfaction is the feelings felt by people after they compare their perception with the reality they receive (Schiffman \& Kanuk, 2007). Managers are considered successful if visitors experience a high level of satisfaction (Ghani, 2015). Visitor satisfaction is considered to be a benchmark of whether the managers are able to provide the services that customers want (Ahmadia, 2017).

Service quality is a very important factor to customers. Service quality refers to the quality received by customers (Yarimoglu, 2014). The better the quality of the service provided, the greater the likelihood customers will visit the same place again (Park, 2011). Services with good quality and in line with expectations are expected to improve 
customer satisfaction and loyalty (Gunarto, 2013).

In developing loyalty, brand personality is viewed as the trait which best communicate the brand to target customers. Brands do not only present physical products with written names or logos or symbols from the company. Brands also show the loyalty of their users. As a result, customers feel that the brand is a part of them (Afzal et al., 2010). Products that create and communicate a special brand personality will be more capable to survive the competition and maintain loyalty (Aaker, 2004). The purpose of this study is to examine and analyze the role of customer satisfaction in mediating the influence of brand personality and service quality on the loyalty of Beachwalk Shopping Center customers. This research is expected to be a reference for other studies and managers in developing their strategies to increase customer loyalty.

\section{Literature Review}

\subsection{Expectation Disconfirmation Theory (EDT)}

The expectancy disconfirmation theory explained that the assessment of satisfaction is determined not only by the performance of the product or service, but also the process in which consumers compare product performance with their initial expectations (Van Ryzin, 2006). Ratnasari (2015) stated that when the disconfirmation is positive, the users of the service will be satisfied, while if it is negative, service users will be dissatisfied.

\subsection{Service Quality (SERVQUAL)}

Service quality here refers to the perceived quality received by customers (Yarimoglu, 2014). The service quality dimension in the SERVQUAL model is based on a multi-item scale designed to measure customer expectations and perceptions (Sivakumar et al., 2014). Parasuraman et al., (1988) perfected these dimensions into physical evidence (tangibles), empathy, reliability, responsiveness, and assurance.

\subsection{Brand Personality}

Kotler and Keller (2009) defined brand personality as "the specific mix of human traits that we can attribute to a particular brand". Aaker (2004) identified brand personality into five dimensions, namely sincerity, excitement, competence, sophistication and ruggedness. Products that create and communicate a special brand personality are more likely to survive in the competition and maintain longer years of loyalty.

\subsection{Customer Satisfaction}

Satisfaction is the feelings of people after they compare their perception with the reality they get (Schiffman \& Kanuk, 2007). Customer satisfaction is considered to be a benchmark of whether the managers are able to provide the services that customers want (Ahmadia, 2017). Managers are considered successful if visitors experience a high level of satisfaction (Ghani, 2015).

\subsection{Customer Loyalty}

Krittinger (2005) defined loyalty as the behavioral tendency of customers to make routine purchases. Hennig and Hansen (2000) pointed out that customer loyalty is the positive attitude of customers towards the products or service providers. To make customers loyal is an attractive strategic goal for researchers and managers (El Hedhli et al., 2013)

\section{Hypothesis Development and Conceptual Model}

The conceptual framework of this study is presented in the following figure. 


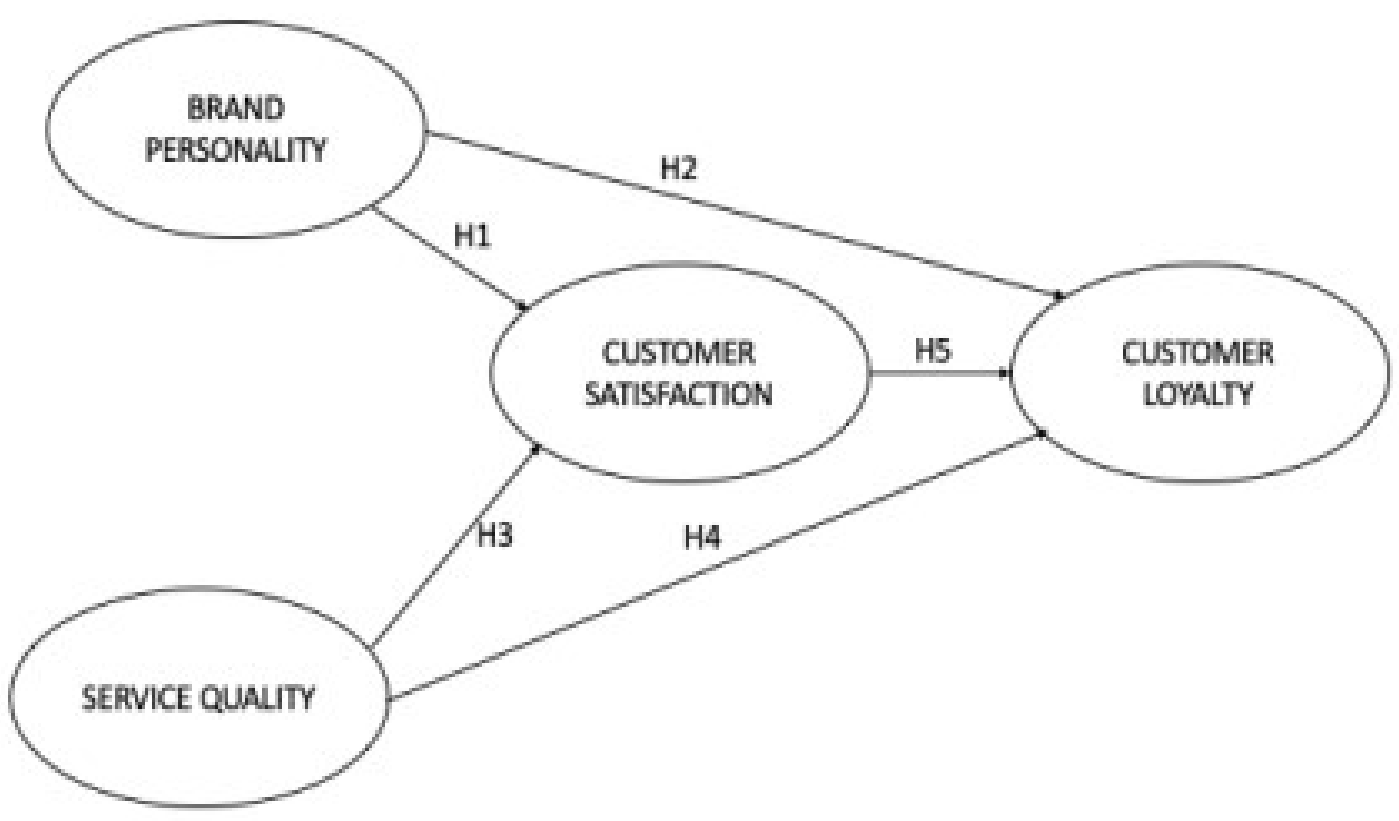

Figure 1. Conceptual Framework

\subsection{The Influence of Brand Personality On Customer Satisfaction}

The study conducted by $\mathrm{Chan} \mathrm{Wu}$ (2011) revealed that brand personality has a positive and significant influence on the satisfaction of hospital customers in Taiwan. This is in line with the results obtained by Kim and Lee (2015) and Anita (2019) which stated that brand personality is able to develop the satisfaction of shopping center visitors. Based on this explanation, the hypothesis is as follows:

$\mathrm{H} 1$ : Brand personality has a positive and significant influence on customer satisfaction

\subsection{The Influence of Brand Personality On Customer Loyalty}

The study conducted by Anita (2019) revealed that brand personality has a positive and significant influence on customer loyalty. In contrast, Polyrat (2011) stated that brand personality has an insignificant impact on loyalty and is attitudinal and behavioral in nature. Yusoff and Salleh (2015) stated that brand personality is not correlated with loyalty, because brand personality is only an important purchase reference factor for customers of the small and medium business sector. Based on the discussed reviews, the hypothesis is formulated as follows:

$\mathrm{H} 2$ : Brand personality has a positive and significant influence on customer loyalty

\subsection{The Influence of Service Quality On Customer Satisfaction}

The study conducted by Al-Shammari and Samer Kanina (2014) stated that service quality has a significant and positive influence on customer satisfaction. This statement is supported by Ruswanti (2012) who found that service quality is the most important factor in developing customer satisfaction. Likewise, the research by Hidayat and Asnawi (2019) and Ahmad (2012) found conforming results. Based on the discussed findings, the following hypothesis is formulated:

H3: Service quality has a positive and significant influence on customer satisfaction

\subsection{The Influence of Service Quality On Customer Loyalty}

The study conducted by Hidayat and Asnawi (2019) stated that service quality has a positive and significant influence on customer loyalty. Similarly, Ahmad (2012) stated that service quality is a significant factor that influence visitor loyalty. However, Leninkumar (2016) and Kheng and Mahamad (2010) found that service quality has no influence on customer loyalty. Based on this discussion, the hypothesis is as follows:

H4: Service quality has a positive and significant influence on customer loyalty

\subsection{The Influence of Customer Satisfaction On Customer Loyalty}

The research conducted by Ahmad (2012) and Al-Shammari and Samer Kanina (2014) revealed that customer 
satisfaction has a significant and positive influence on customer loyalty. In line with these two studies, Ruswanti (2012), Hidayat and Asnawi (2019), Kheng and Mahamad (2010) and Ahmad (2012) also obtained similar results. Based on this description, the hypothesis is formulated as follows:

H5: Customer satisfaction has a positive and significant influence on customer loyalty

3.6 The Role of Customer Satisfaction in Mediating The Influence of Brand Personality on Customer Loyalty

The study conducted by Anita (2019) revealed that customer satisfaction has the most significant and positive influence in mediating the influence of brand personality on customer loyalty. This was conformed by Kim and Lee (2015) who stated that customer satisfaction is the most important factor to consider in improving the influence of brand personality on the loyalty of shopping center customers in Korea. Based on this review, the following hypothesis is formulated:

H6: Customer satisfaction mediates the influence of brand personality on customer loyalty

3.7 The Role of Customer Satisfaction in Mediating The Influence of Service Quality on Customer Loyalty

Chan $\mathrm{Wu}$ (2011) stated that customer satisfaction is able to mediate the influence of service quality on customer loyalty. Chuan Wu and Lun Hsu (2011), Pratiwi and Wardi (2019), Kheng and Mahamad (2010), and Hidayat and Asnawi (2019) also stated that customer satisfaction is able to mediate the influence of service quality on customer loyalty. Based on this review, the formulated hypothesis is as follows:

H7: Customer satisfaction mediates the influence of service quality on customer loyalty

3.8 The Difference in Customer Satisfaction and Loyalty Between The Local Customers and Foreign Customers of Beachwalk Shopping Center

The studies by Chang and Gibson (2011) and Rohman and Nasution (2019) stated that the satisfaction of foreign tourists is higher than local visitors. However, McDowall and Ma's research (2010) found that the satisfaction of foreign tourist is lower than domestic visitors. The study conducted by Chang and Gibson (2011) also revealed that the loyalty of foreign tourists is lower than that of domestic visitors in watching shows and enjoying festivals. Conforming to the two studies above, McDowall and Ma's (2010) also found that the loyalty of foreign visitors is lower than domestic visitors. Thus, the following hypotheses are presented:

H8a: The satisfaction of foreign customers is lower than local customers

H8b: The loyalty of foreign customers is lower than local customers

\section{Research Methodology}

This research is a quantitative associative study which discusses the relationship between the variables of brand personality, service quality, customer satisfaction and customer loyalty. The study was conducted at Beachwalk Shopping Center, Bali. The sample was determined using the non-probability sampling technique with the purposive sampling approach. The sample in this study amounted to 218 foreign and local visitors to Beachwalk Shopping Center, Bali. The data were collected by utilizing the questionnaire which contained open ended and closed ended questions with the 5-point Likert scale.

The brand personality construct in this study adapted and modified the indicators used in the research conducted by Anita (2019), service quality adapted and modified the indicators used by Sahin and Kitapci (2017), customer satisfaction adapted and modified the indicators used in the research conducted by Ahmad (2012), and customer loyalty adapted and modified the indicators used in the research conducted by Jones and Sasser (1995). The analysis technique used is the Structural Equation Model (SEM) and analysis tool was the SmartPLS 3.0.

\section{Data Analysis}

\subsection{Characteristics of Respondents}

The characteristics of respondents in this study were divided into several categories, namely gender, age, occupation, income per month, and frequency of visits in 1 month. There were 218 respondents in this study. From the data obtained, the categories of respondents that visited Beachwalk Shopping Center most frequently were female respondents, visitors with an age of 26 - 30 years old, those who have an undergraduate degree, and respondents who are already working. Based on the income, a majority of the respondents have an income between one million and five million rupiah. This means that the visitors are already able to shop and fulfill their own fashion needs. 


\subsection{Instrument Test Results}

Instrument validity and reliability test

All variable instruments in this study have a correlation coefficient value above 0.30 which means that they have fulfilled the instrument validity requirements. All the variable instruments in this study have a Cronbach's Alpha $(\alpha)$ value of greater than 0.60 . This means that all the instruments in this study are reliable.

\subsection{Measurement Model}

\subsubsection{Convergent validity, discriminant validity and composite reliability}

All the indicators in this study have an outer loading value of greater than 0.5 indicates that the model has fulfilled convergent validity requirement. All construct variables in this study have a discriminant validity which is categorized as quite good because the average variance extracted (AVE) value is greater than 0.50 and the Cronbach's Alpha value exceeds 0.60. Composite reliability and Cronbach's Alpha values are considered to be good if they have values $>0.70$. In this study, the composite reliability and Cronbach's alpha values of all the constructs are greater than 0.7 .

\subsubsection{Inner model}

The inner model test is conducted to examine the relationship between the constructs, the significance value and the R-square value of the research model. The R-square value in this study is presented in Table 2.

Table 2. R-square Value of the Dependent Variables

\begin{tabular}{ccc}
\hline Variable & R-square & Adjusted R-square \\
\hline Customer satisfaction $\left(\mathrm{Y}_{1}\right)$ & 0,624 & 0,621 \\
Customer loyalty $\left(\mathrm{Y}_{2}\right)$ & 0,662 & 0,616
\end{tabular}

Source : Computed primary data, 2020

$$
\begin{array}{ll}
\mathrm{Q}^{2} & =1-\left(1-\left(\mathrm{R}_{1}\right)^{2}\right)\left(1-\left(\mathrm{R}_{2}\right)^{2}\right)=1-(1-0,624)(1-0,662) \\
= & 0,873
\end{array}
$$

From the calculation, the Q2 value is 0.873 which indicates that the model has a good predictive relevance. It can be interpreted that 87.3 percent of the variation in customer loyalty is influenced by brand personality, service quality, and customer satisfaction, while the remaining 12.7 percent is influenced by other variables not included in this research model.

\subsection{Direct influence}

The results of the analysis test using the partial least square analysis is presented in Figure 2.

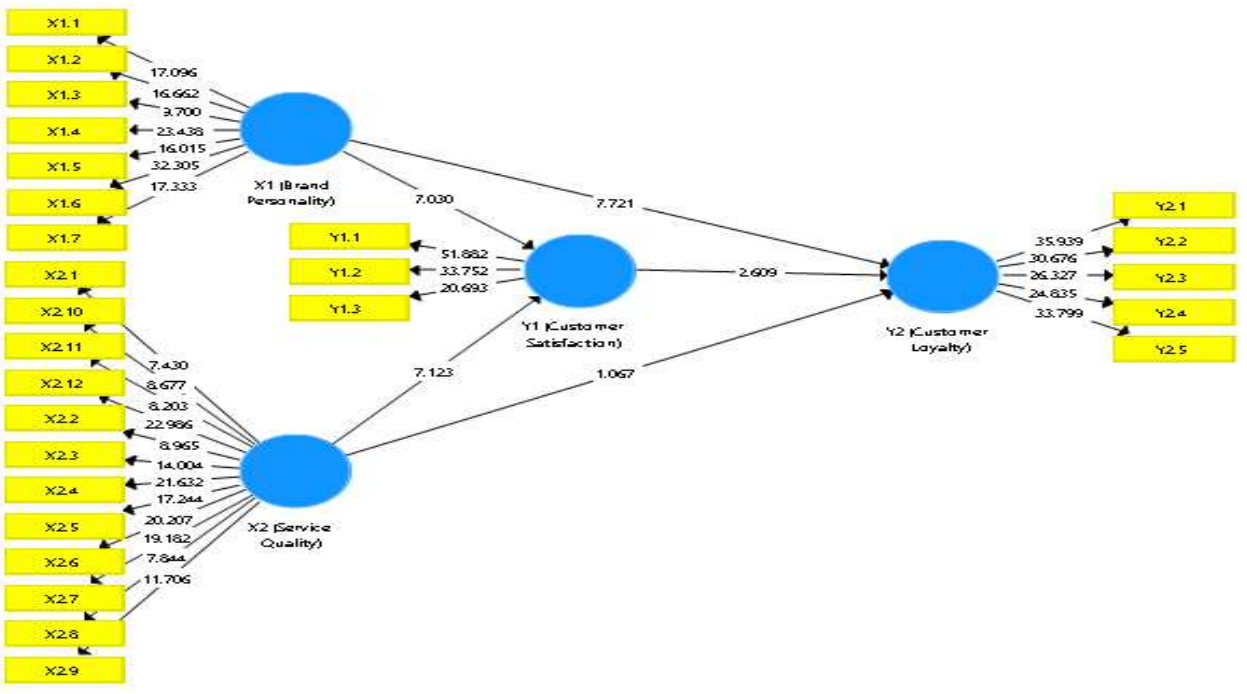

Figure 2. Structural Model 
From the calculation, the Q2 value obtained is 0.873 , which indicates that the model has a good predictive relevance. Thus, 87.3 percent of variation in customer loyalty is influenced by brand personality, service quality, and customer satisfaction, while the remaining 12.7 percent is influenced by other variables not included in the research model.

\subsection{The indirect influence and the total influence}

Table 3. shows the total influence test results between the research variables.

Table 3. Test Results of the Total Influence between Variables

\begin{tabular}{lcccc}
\hline \multicolumn{1}{c}{ Path Coefficient Between Variables } & $\begin{array}{c}\text { Path } \\
\text { Coefficient }\end{array}$ & t-Statistics & P Value & Remarks \\
\hline $\begin{array}{l}\text { Brand personality } \quad\left(\mathrm{X}_{1}\right) \rightarrow \text { Customer } \\
\text { satisfaction }\left(\mathrm{Y}_{1}\right)\end{array}$ & 0,442 & 7,030 & 0,000 & Significant \\
$\begin{array}{l}\text { Brand personality }\left(\mathrm{X}_{1}\right) \rightarrow \text { Customer loyalty } \\
\left(\mathrm{Y}_{2}\right)\end{array}$ & 0,548 & 7,721 & 0,000 & Significant \\
$\begin{array}{l}\text { Service quality } \quad\left(\mathrm{X}_{2}\right) \rightarrow \text { Customer } \\
\text { satisfaction }\left(\mathrm{Y}_{1}\right)\end{array}$ & 0,422 & 7,123 & 0,000 & Significant \\
$\begin{array}{l}\text { Service quality }\left(\mathrm{X}_{2}\right) \rightarrow \text { Customer loyalty } \\
\left(\mathrm{Y}_{2}\right)\end{array}$ & 0,097 & 1,067 & 0,286 & Insignificant \\
$\begin{array}{l}\text { Customer satisfaction }\left(\mathrm{Y}_{1}\right) \rightarrow \text { Customer } \\
\text { loyalty }\left(\mathrm{Y}_{2}\right)\end{array}$ & 0,210 & 2,609 & 0,009 & Significant \\
\hline
\end{tabular}

Source: Computed Primary Data, 2020

The indirect influence test result is displayed in Table 4.

Table 4. Test Results of the Indirect Influence Between Variables

\begin{tabular}{|c|c|c|c|c|c|}
\hline \multirow{2}{*}{ Variable Mediation } & \multicolumn{4}{|c|}{ Influence } & \multirow{2}{*}{ Remarks } \\
\hline & (A) & (B) & (C) & (D) & \\
\hline $\begin{array}{l}\text { Brand personality }(\mathrm{X} 1) \rightarrow \text { Customer } \\
\text { satisfaction }(\mathrm{Y} 1) \rightarrow \text { Customer loyalty } \\
(\mathrm{Y} 2)\end{array}$ & 0,093 (Sig.) & $\begin{array}{l}0,548 \\
\text { (Sig.) }\end{array}$ & $\begin{array}{l}0,442 \\
\text { (Sig.) }\end{array}$ & $\begin{array}{l}0,210 \\
\text { (Sig.) }\end{array}$ & $\begin{array}{c}\text { Partial } \\
\text { Mediation }\end{array}$ \\
\hline $\begin{array}{l}\text { Service quality }(\mathrm{X} 2) \rightarrow \text { Customer } \\
\text { satisfaction (Y1) } \rightarrow \text { Customer loyalty } \\
(\mathrm{Y} 2)\end{array}$ & 0,088 (Sig.) & $\begin{array}{c}0,097 \\
\text { (Non Sig.) }\end{array}$ & $\begin{array}{l}0,422 \\
\text { (Sig.) }\end{array}$ & $\begin{array}{l}0,210 \\
\text { (Sig.) }\end{array}$ & Full Mediation \\
\hline
\end{tabular}

Source: Computed primary data, 2020

The direct influences and total influences in the inner model are examined by assessing the t-statistics and the pvalue. If the t-statistics value $\geq \mathrm{t}$-table value (1.96) or $\mathrm{p}$-value $<0.05$, it can be concluded that the influence is positive and significant. Based on Table 3. the relationship between brand personality and customer satisfaction has a t-statistics value of $7.030 \geq \mathrm{t}$-table value $(1.96)$ and a $\mathrm{p}$-value of $0,000<0.05$. Thus, $\mathrm{H} 1$, which states that brand personality has a positive and significant influences on customer satisfaction, is accepted. The relationship between brand personality and customer loyalty has a t-statistics value of 7,721 $\geq \mathrm{t}$-table value (1.96) and a $p$ value of $0,000<0.05$. Thus, $\mathrm{H} 2$, which states that brand personality has a positive and significant influence on customer loyalty, is accepted. The relationship between service quality and customer satisfaction has a t-statistics value of $7.123 \geq$ t-table value (1.96) and a p-value of $0,000<0.05$. Thus, $\mathrm{H} 3$, which states that service quality has a positive and significant influence on customer satisfaction, is accepted.

The relationship between service quality and customer loyalty has a t-statistics value of $1.067 \leq \mathrm{t}$-table value (1.96) and has a p-value of $0.286>0.05$. This indicates that $\mathrm{H} 4$, which states that service quality has a positive and significant influence on customer loyalty, is rejected. The relationship between customer satisfaction and customer loyalty has a $\mathrm{t}$-statistics value of $2.609 \geq \mathrm{t}$-table value $(1.96)$ and a $\mathrm{p}$-value of $0.009<0.05$. This indicates that $\mathrm{H} 5$ is accepted, which means that customer satisfaction has a positive and significant influence on customer loyalty.

The variable with the greatest influence on the customer loyalty is brand personality with a coefficient of 0.548 , 
while service quality has a coefficient of 0.097 and customer satisfaction has a coefficient of 0.210 . Based on Table 3. it can be concluded that customer satisfaction is able to partially mediate the relationship between brand personality and customer loyalty. Thus, H6 is accepted. Customer satisfaction is also able to partially mediate the relationship between service quality and customer loyalty, which means that $\mathrm{H} 7$ is accepted.

To compare the satisfaction and loyalty of local and foreign customers, the significance value of t-statistic T-Test is $0,961<1,96$ for customer satisfaction and $-1,742<1,96$ for customer loyalty. Thus, H8a and H8b are rejected. This means that there are no significant differences in satisfaction and loyalty between local and foreign visitors as the average value of both of their satisfaction and loyalty are equally high.

\section{Research Findings and Discussions}

\subsection{The influence of brand personality on customer satisfaction}

The analysis result shows that brand personality has a positive and significant influence on customer satisfaction. This means that the more the brand personality of Beachwalk Shopping Center conforms with visitors' preference, the higher the satisfaction of these visitors. This study supports the research results obtained by Chan Wu (2011), Kim and Lee (2015) and Anita (2019) which revealed that brand personality has a positive and significant influence on customer satisfaction.

\subsection{The influence of brand personality on customer loyalty}

The analysis showed that brand personality has a positive and significant influence on customer loyalty. This means that the more the brand personality of Beachwalk Shopping Center conforms with visitors' preference, the higher the loyalty of these visitors. This study supports the results obtained by Anita (2019) and Polyrat (2011) which proved that brand personality has a positive and significant influence on visitor loyalty.

\subsection{The influence of service quality on customer satisfaction}

The analysis result shows that service quality has a positive and significant influence on customer satisfaction. This means that the better the service quality perceived by visitors, the higher the satisfaction of Beachwalk Shopping Center visitors. This study supports the results obtained by Al-Shammari and Kanina (2014), Ruswanti (2012), Hidayat and Asnawi (2019) and Ahmad (2012) which revealed that service quality has a positive influence on customer satisfaction.

\subsection{The influence of service quality on customer loyalty}

The analysis result shows that service quality has a positive but insignificant influence on customer loyalty. This means that the better the service quality provided by Beachwalk Shopping Center, the higher their loyalty, but not to a significant extent. This research supports the results obtained by Hidayat and Asnawi (2019) and Ahmad (2012) which proved that service quality is a factor that influences the loyalty of customers. However, in this study, service quality was found to have a positive but insignificant influence on customer loyalty.

\subsection{The influence of customer satisfaction on customer loyalty}

The analysis shows that customer satisfaction has a positive and significant influence on customer loyalty. This means that the higher the satisfaction of Beachwalk Shopping Center customers, the higher their loyalty. This supports the results obtained by Ahmad (2012), Al-Shammari and Samer Kanina (2014), Ruswanti (2012), Hidayat and Asnawi (2019), and Kheng and Mahamad (2010) which revealed that customer satisfaction has a positive and significant influence on customer loyalty.

\subsection{The role of customer satisfaction in mediating the influence of brand personality on customer loyalty}

The analysis shows that customer satisfaction is able to mediate the influence of brand personality on customer loyalty. This means that with a higher level of customer satisfaction, brand personality will have a greater influence on the loyalty of Beachwalk Shopping Center customers. The result of this study supports the studies conducted by Anita (2019) and Kim and Lee (2015) which revealed that customer satisfaction significantly mediates the relationship between brand personality and customer loyalty.

\subsection{The role of customer satisfaction in mediating the influence of service quality on customer loyalty}

The analysis result shows that customer satisfaction is able to mediate the influence of service quality on customer loyalty. This means that with a higher level of customer satisfaction, service quality will have a greater influence on the loyalty of Beachwalk Shopping Center customers. This result agrees with Chan Wu (2011), Pratiwi and Wardi (2019), Chuan Wu and Lun Hsu (2011), Kheng and Mahamad (2010), and Hidayat and Asnawi (2019) who stated that customer satisfaction significantly mediates the influence of service quality on customer loyalty. 
6.8 The difference in satisfaction and loyalty between the local customers and foreign customers of Beachwalk Shopping Center

The analysis result shows that there is no significant difference in customer satisfaction and customer loyalty between the local visitors and foreign visitors of Beachwalk Shopping Center. It can be concluded that hypotheses $8 \mathrm{a}$ and $8 \mathrm{~b}$ are rejected. This result does not support the results obtained by McDowall and Ma (2010) which revealed that the satisfaction of foreign visitors is lower than domestic visitors due to the negative issues and images that make them feel less comfortable and safe when they visit the tourist sites. Chang and Gibson (2011) stated that the loyalty of foreign tourists is lower than domestic visitors in watching performances and enjoying festivals. This result is also not in line with Rohman and Nasution's research (2019) which stated that the loyalty of foreign tourist visitors is lower than domestic visitors in visiting Prambanan Temple.

\section{Implications, limitations and further research}

This research model enriches the literature related to the concept of consumer behavior by proving that customer satisfaction, service quality, and brand personality have a positive and significant influence on the loyalty of Beachwalk Shopping Center customers. The practical implication in this research is that the managers of Beachwalk Shopping Center should develop the right brand personalization strategy to produce the greatest positive influence on customer loyalty. This is because if the brand personality is not in line with the customers' preferred trait, it is likely that they will immediately move to other shopping centers.

The scope of this research is limited to examining the visitors of Beachwalk Shopping Center, therefore the results cannot be generalized for other conditions. This research was also conducted over a certain period of time, while the environment is dynamic. Therefore, this research should be conducted again in different regions, over a different and extended time period, or with different product or service categories. This study only examined customer satisfaction, brand personality and service quality as the variables that influence customer loyalty. Future studies can also examine other variables to provide more insights on how to develop customer loyalty.

\section{References}

Aaker, J.L. (1997), "Dimension of Brand Personality”, Journal of Marketing Research. 34 :2, 347-56. DOI : $10.2139 /$ ssrn. 945432

Aaker, J.L. (1999), "The Malleable-Self : The Role of Self-Expression in Persuasion", Journal of Marketing Research. 36:1 , 45-57. DOI:10.2139/ssrn.945453

Aaker ,(2004), “Strategic Marketing Manajemen”, New York: John Wiley \& Sons, Inc.

Abidin, I.H.Z., Piah, Z.H.M., \& Usman, S.B. (2016), "Investigating Antecedents of Cross Shopping. Behavior among Consumers in Selangor”, Procedia Economics and Finance, 37(16), 397-404.

Ahmad, Khalaf Mohamad. (2012), “Attractiveness Factors Influencing Shoppers’ Satisfaction, Loyalty, and Word of Mouth: An Empirical Investigation of Saudi Arabia Shopping Malls”, International Journal of Business Administration, 3 : 6. DOI : 10.5430/ijba.v3n6p101

Abubakar,Ahmed, (2016),'Impact of Perceived Service Quality by Mobile Telecommunication Industry on Customer Satisfaction in Nigeria", International Journal of Advanced Research,4(4),845-852. DOI : 10.21474/IJAR01.

Al-Shammari, Minwir, and Kanina, Ahmad. (2014), "Service Quality And Its Relationship With Customer Satisfaction And Loyalty In A Saudi Arabian Automobile Company”, Global Journal of Management and Business Research: E Marketing, 14 : 8.

Alves, Amelia, Da Silva,Alexnaldo, \& De Lara, Barbara. (2019), "Quality of Experience and Satisfaction: A Same Psychological Construct", International Review of Management and Business Research, 8(1), 36-52. DOI : 10.30543/8-1(2019)-4

Andreassen, W. (1999), “What drives customer loyalty with complaint resolution?” Journal of Service Research, 1: 4, 324-32. DOI: 10.1177/109467059914004

Anita, Lily Tiurida. (2019), "The Effect of Brand Personality and Customer Satisfaction to Customer Loyalty at The Mall: A Study Case”, International Journal of Tourism \& Hospitality in Asis Pacific, 2 : 1. DOI : 10.32535/ijthap.v2i1.352 
Anselmsson, J. (2006), "Sources of customer satisfaction with shopping malls: a comparative study of different customer segments". International Review of Retail, Distribution and Consumer Research, 16:1, 115-138. DOI : 10.1080/09593960500453641

Antaranews.com. (2018, August 8th). BI: positif, pertumbuhan ritel kekinian di Bali. [Online] Available : https://bali.antaranews.com/berita/130647/bi-positif-pertumbuhan-ritel-kekinian-di-bali $\left.15^{\text {th }}, 2020\right)$

(March

Aryani, D., \& Rosinta, F. (2010), "Pengaruh Kualitas Layanan terhadap Kepuasan Pelanggan dalam Membentuk Loyalitas Pelanggan”, Jurnal Ilmu Administrasi Dan Organisasi, 17: 2, 114-126. ISSN: 0854-3844 / Online ISSN: 2355-7826.

Aziz, A., \& Zainol, N. A. (2009), "Local and foreign tourists' image of highland tourism destinations in Peninsular Malaysia", Pertanika Journal of Social Science and Humanity, 17:1, 33-45. ISSN 0128-7702; ESSN: 2231-8534

Babin, B.J., Gonzalez, C. and Watts, C., (2007), "Does Santa have a great job? Gift shopping value and satisfaction”, Psychology \& Marketing, 24: 10, 895-917. DOI : 10.1002/mar.20189

Balitribune.co.id. (2019, 15 Agustus). BI: IPR Bali Tumbuh Positif. [Online] Available : https://balitribune.co.id/content/bi-ipr-bali-tumbuh positif (March $\left.15^{\text {th }}, 2020\right)$

Boeselie, P., Hesselink, M. dan Wiele, T.V. (2002), "Empirical evidence for the relationship Between Customer Satisfaction and Business Performance", Managing Service Quality, 12 : 3. DOI : $10.1108 / 09604520210429259$

Cakici, Celil, and Akgunduz, Yilmaz. (2018), “ The impact of perceived price justice and satisfaction on loyalty: the mediating effect of revisit intention”, Emerald Insight Publishing Limited. DOI : 10.1108/TR-022018-0025

Chao, Chan Wu (2011), "The impact of hospital brand image on service quality, patient satisfaction and loyalty", African Journal of Business Management .5: 12.4873-4882. DOI : 10.5897/AJBM10.1347

Chang, Seohee and Gibson, Heather.(2011), "The role of satisfaction and involvement in loyalty: Comparing residents and tourists", Travel and Tourism Research Association: Advancing Tourism Research Globally, 73.

Chebat,Jean-Charles and Michon, Richard. (2014), "The effects of mall renovation on shopping values, satisfaction and spending behaviour", Journal of Retailing and Consumer Services 21, 610-618. DOI : 10.1016/j.jretconser.2014.04.010

Chen, C.-F. (2008), "Investigating structural relationships between service quality, perceived value, satisfaction, and behavioral intentions for air passengers: Evidence from Taiwan”, Transportation Research Part A 42, 709-717. DOI : 10.1016/j.tra.2008.01.007

Cheng, C.C., Chiu, S.I., Hu, H.Y. and Chang, Y.Y. (2011), A study on exploring the relationship between customer and loyalty in the fast food industry: With relationship inertia as a mediator", African Journal of Business Management, 5:13, 5118-5126. DOI : 10.5897/AJBM10.870

Chuan Wu, Liao, Hsien. (2011),"Service Quality, Brand Image and Price Fairness Impact on the Customer Satisfaction and Loyalty", IEEE IEEM, 1160 -1164.

Cronin, J. J., Taylor, S. A. (1992), "Measuring service quality: a reexamination and extension", Journal of Marketing, $56: 3$, 55-68. DOI : 10.2307/1252296

Edvardsson, B., Johnson, D., Gustafsson, A., \& Strandvik, T. (2000), "The effects of satisfaction and loyalty on profits and growth: products versus services", Total Quality Management, 11, 917-927. DOI : $10.1080 / 09544120050135461$

Fornell, C. and Larcker, D. (1981), "Evaluating structural equation models with unobservable variables and measurement error", Journal of Marketing Research, 18 : 1, 39-50. DOI: $10.2307 / 3151312$

García, Oviedo M. Á., Vega-Vázquez, M., Castellanos-Verdugo, M., \& Reyes Guizar, L. A. (2014), “Tourist satisfaction and the souvenir shopping of domestic tourists: extended weekends in Spain”, Current Issues in Tourism, 19(8), 845-860. DOI:10.1080/13683500.2013.877423

Gro nroos, C. (1994), "From marketing mix to relationship marketing: towards a paradigm shift in marketing", Management Decisions, 32 : 2. 4-20. DOI : 10.1108/00251749410054774 
Gro n̈roos, C. (1995), "Relationships marketing: the strategy continuum”, Journal Marketing Science, $23:$ 4, 252-255.

of the Academy of

Hallowell, R. (1996), “The relationships of customer satisfaction, customer loyalty, and profitability: an empirical study", International Journal of Service Industry Management, 7:4, 27-42. DOI : $10.1108 / 09564239610129931$

Hidayat, Firman and Asnawi, Nur (2019), "Effect of service quality against visitor loyalty through visitor satisfaction", Management and Economics Journal 3:2. DOI : 10.18860/mec-j.v3i2.6465

Husein,Umar. (2011), “Metode Penelitian Untuk Skripsi dan Tesis Bisnis”, Edisi $11 \quad$ Jakarta: $\quad$ PT .Raja Grafindo Persada, 11, 164.

Jacoby, J., \& Chestnut, R. (1978), "Brand Loyalty: Measurement and Management”, NY: John Wiley and Sons. DOI : 10.1080/00913367.1979.10717981

Jennifer L Aaker. (1997), "Dimension of Brand Personality", Journal of Marketing Research 34 : 3 . DOI : $10.2307 / 3151897$

Jennifer, Aaker, \& Azoulay. (2003), “Do Brand Personality scales really measure Brand Personality ?”, Journal Brand Management, 149. DOI : 10.1057/palgrave.bm.2540162

Kartikasari, D., Dewanto, A., \& Rochman, F. (2014), "Pengaruh Kualitas Layanan terhadap Kepuasan dan Kepercayaan di Rumah Sakit Bunda Kandangan Surabaya”, Jurnal Aplikasi Manajemen 12: 3, 454-463.

Keating, B., Rugimbana, R., \& Quazi, A. (2003), "Differentiating between service quality and relationship quality in cyberspace", Managing Service Quality, 13:3, 217-232.

Kettinger, William J. and Choong. (2005), “Zones of Tolerance: Alternative Scales for Measuring Information Systems Service Quality”, MIS Quarterly, 29 :4. DOI : 10.2307/25148702

Kheng, Lo Liang and Mahamad, Osman. (2010), “The Impact of Service Quality on Customer Loyalty: A Study of Banks in Penang, Malaysia”, International Journal of Marketing Studies, $2: 2$.

Kim, Y. H., Lee, M. Y. and Kim, Y. K. (2011), “A new shopper typology: Utilitarian and hedonic perspectives",Journal of Global Academy of Marketing, 21:2, 102-113.DOI: 10.24052/JBRMR/V13IS01/ART-12

Kim, J. W., Lee, F. and Suh, Y. G. (2015), "Satisfaction and loyalty from shopping mall experience and brand personality”, Services Marketing Quarterly, 36: 1, 62-76. Doi : 10.1080/15332969.2015.976523

Knox, D., \& Denison, J. (2000), "Store loyalty: its impact on retail revenue. An empirical study of purchasing behaviour in the UK",Journal of Retailing and Consumer Services, 7:1, 33-45. DOI: 10.1016/S0969-6989(98)00033-2

Kotler,P., \& Keller,K.L. (2012), “Marketing Management, $14^{\text {th }}$ Edition”, Pearson Education.New Jersey.

Kotler, Phillip and Armstrong, Gary. (2014), “Principle of Marketing 15 ${ }^{\text {th }}$ Edition”, Pearson Prentice Hall. New Jersey.

Lai, C., \& Nguyen, M. C. (2017), "Factors affecting service quality, customer satisfaction and loyalty of mobile phone service providers in Vietnam", International Journal of Organizational Innovation $10: 2,75-86$.

Lee, Fredy, Kim (2015), "Satisfaction and Loyalty From Shopping mall Experience and Brand Personality", Service Marketing Quarterly. 36, 62-76. DOI : 10.1080/15332969.2015.976523

Leasing Report beachwalk Shopping Center. (2019), Cornerstone Management. Bali.

Leninkumar, Vithya. (2016), “The Effect of Service Quality on Customer Loyalty”, European Journal of Business and Management, $8: 33$.

Liu, Chia-Ming and Wang, Tsung-Yuan. (2017), “A study on the effect of service quality on customer loyalty and corporate performance in financial industr", Problems and Perspectives in Management, 15:2,355-363.

Liu, C.H.S. and Lee, T. (2016), "Service quality and price perception of service: influence on word-of- mouth and revisit intention", Journal of Air Transport Management, 52, 42-54.

Liu, Y. and Jang, S. (2009), "Perceptions of Chinese restaurants in the US: what effects customer satisfaction and behavioral intentions?", International Journal of Hospitality Management, 28 : 3, 338-348. DOI : 10.1016/j.ijhm.2008.10.008

Lloyd, A.E., Chan, R.Y.K., Yip, L.S.C., \& Chan, A. (2014), “Time buying and time saving: Effects on service 
convenience and the shopping experience at the mall”, Journal of Services Marketing, 28 : 1, 36-49.DOI : 10.1108/JSM-03-2012-0065

Lovelock, C. H., \& Wright, L. (2002), “Principles of service marketing and management, 2nd ed”, New Jersey: Prentice Hall.

Lynch, J., \& Ariely, D. (2000),"Wine Online: Search Costs Affect Competition on Price, Quality and Distribution", Marketing Science, 19:1, 83-103. DOI : 10.1287/mksc.19.1.83.15183

Mansori,Shaheen dan Chin, Jin Huey. (2019), "Shopping Mall Attributes: Tourist Satisfaction and Loyalty", Management Dynamics in the Knowledge Economy, 7:4, 571-590. DOI : 10.25019/MDKE/7.4.08

Makgopa, SS. (2018), "Determining Shopping mall customers satisfaction and loyalty", Journal of Business and Retail Management Research (JBRMR), $13: 1$. DOI : 10.24052/JBRMR/V13IS01/ART-12

Mc Dowall, Siriporn and Ma, Emily. (2010), “An Analysis of Tourists Evaluation of Bangkok's Performance Satisfaction and Destination Loyalty : Comparing International Versus Domestic Thai Tourists”, Journal of Quality Assurance in Hospitality \& Tourism 11:4, 260-282. DOI: 10.1080/1528008X.2010.504181

Naseeb, S., Shah, U., \& Jan, S. (2018), "Role of Service Quality and Customer Satisfaction in Firm 's Performance : Evidence from Pakistan”, Pakistan Journal of Commerce and Social Sciences (PJCSS) 12 : 1, 167-182.

Oliver, R. (1997), “Satisfaction, a behavioral perspective on the consumer”, New York : Mc Graw-Hill.

Oliver, R .L (1999), “Whence consumer loyalty?”. Journal of Marketing, 63, 33-44 . DOI: 10.2307/1252099

Oliver, R .L . (2010), "Satisfaction: A Behavioral Perspective on the Consumer”, Armonk, NY: M .E .Sharpe.

Olsen, L. L. and M. D. Johnson. (2003), "Service Equity, Satisfaction, and Loyalty: From Transaction-Specific to Cumulative Evaluations”, Journal of Service Research, 5 : 3, 184-195. DOI : 10.1177/1094670502238914

Parasuraman, A ., Zeithaml, V .A . \& Berry, L .L . (1985), “A conceptual model of service quality and its implications for future research", Journal of Marketing, 49, 41-50 . DOI: 10.12691/jbms-4-5-2

Parasuraman, A., Zeithaml, V . A., \& Berry, L. L. (1994), "Reassessment of Expectations as a Comparison Standard in Measuring Service Quality : implications", Furtiier Research, 58, 111-124. DOI : $10.2307 / 1252255$

Parasuraman, A., Zeithaml, A. V ., \& Berry, L. L. (1988) "Servqual: A Multiple Item Scale For Measuring Consumer Perceptions Of Service Quality”, Journal Of Retailing, 64:1,12-40.

Parasuraman, A., Berry, L., \& Zeithaml, V. (1991), "Refinement and reassessment of the SERVQUAL scale". Journal of Retailing, 67, 420-450.

Pontoh, M. B., Kawet, L., \& Tumbuan, W. A. (2014), "Kualitas Layanan, Citra Perusahaan Dan Kepercayaan Pengaruhnya Terhadap Kepuasan Nasabah Bank BRI Cabang Manado”, Jurnal EMBA, 2:3,285-287. DOI : $10.35794 / \mathrm{emba.v2i3.5502}$

Prashar, S., Gupta, S., Singh, H., Vijay, T.S., \& Parsad, C. (2016), "Clustering Shoppers By Mall Experience for Emerging Indian City", Asian Academy of Management Journal, 21 :2, 53-73. DOI : 10.21315/AAMJ2016.21.2.3

Pratiwi, Diza and Wardi, Yunia. (2019), "The Influence of Brand Personality, Service Quality, and Store Atmosphere toward Repurchase Intention Ethic Barbershop Padang", Jurnal Kajian Manajemen dan Wirausaha. $1: 1$.

Putra, I. G. N., Sudiarta, I. N., \& Mananda, I. G. S. (2016), "Pengaruh Kualitas Pelayanan Dan Kepuasan Terhadap Niat Berkunjung Kembali Wisatawan Mancanegara Ke Daya Tarik Wisata Alas Pala Sangeh”. Jurnal IPTA, 4:2, 1-6.

Ramamoorthy, R., Gunasekaran, A., Roy, M., Rai, B. K., Senthilkumar, S. A., Gunasekaran, A., \& Roy, M. (2016), "Total Quality Management \& Business Excellence Service quality and its impact on customers ' behavioural intentions and satisfaction : an empirical study of the Indian life insurance sector", Total Quality Management, 1-14. DOI : 10.1080/14783363.2016.1240611

Rohman, Isnanda and Nasution, Olivia. (2019), “Persepsi Kualitas Layanan Pengunjung Candi Prambanan (Studi Komparasi Wisatawan Lokal Dan Mancanegara)”, Upajiwa Dewantara 3:2, 67-77.

Rousseau, G.G., \& Venter, D.J.L. (2014), "Mall shopping preferences and patronage of mature shoppers", SA Journal of Industrial Psychology, 40:1, 1-13. DOI : 10.4102/sajip.v40i1.1175 
Ruswanti, Endang (2012), "Pengaruh Service Quality Dan Customer Satisfaction Terhadap Customer Loyalty", Widya Universitas Esa Unggul, $29: 318$.

Sahin, Azize, and Kitapci, Hakan. (2017), "Investigating the impacts of brand experience and service quality", International Journal of Market Research, $59: 6$. DOI : 10.2501/IJMR-2017-051

Sholihin, Mahmud and Ratmono, Dwi. (2013), “Analisis SEM-PLS dengan WarpPLS3.0”, Edisi Satu, Yogyakarta : Andi Offset.

Sondakh, C. (2014), "Kualitas Layanan, Citra Merek dan Pengaruhnya Terhadap Kepuasan Nasabah dan Loyalitas Nasabah Tabungan (Studi pada Nasabah Taplus BNI Cabang Manado)”, Riset Bisnis Dan Manajemen, 3: $1,19-32$.

Sugiyono (2014), “ Statistika untuk Penelitian”, Alfabeta. Bandung.

Sugiyono, (2005), “Memahami Penelitian Kualitatif”, Alfabeta. Bandung.

Sugiyono, (2012), “Metode Penelitian Kuantitatif Kualitatif dan R\&D”, Alfabeta. Bandung.

Tariq M. Khizindar. (2015), “An Empirical Study Of Factors Affecting Customer Loyalty Of Telecommunication Industry In The Kingdom Of Saudi Arabia”, British Journal of Marketing Studies, 3: 5,98-115.

Traffic Report beachwalk Shopping Center. (2019) Cornerstone Management. Bali.

Van Ryzin, G. G. (2006), “Testing the Expectancy Disconfirmation Model of Citizen Satisfaction with Local Government". Journal of Public Administration Research and Theory, 16(4), 599-611. DOI: 10.1093/jopart/mui058

Wei Khong, K., \& Sim Ong, F. (2014), "Shopper perception and loyalty: a stochastic approach to modelling shopping mall behaviour", International Journal of Retail \& Distribution Management, 42:7, 626-642.

Westbrook, R. A., \& Reilly, M. D.( 1983), "Value-percept disparity: An alternative to the disconfirmation of expectations theory of consumer satisfaction". In R. P. Bagozzi \& A. M. Tybout (Eds.), Advances in consumer research. Vol. 10, Ann Arbor, MI: Association for Consumer Research, 256-261.

Winadi, Ari, dan Kenny, Andreas. (2016),” Pengaruh Service Quality Dan Brand Image Terhadap Loyalitas Melalui Kepuasan Konsumen Pada Inul Vizta Karaoke Di Jakarta (Studi Kasus Pada Kepuasan Konsumen Inul Vizta Karaoke Di Jakarta)”. Jurnal Ekonomi 7 : 2.

Wong, I.K.A., \& Wan, Y.K.P. (2013), “A Systematic Approach to Scale Development in Tourist Shopping Satisfaction: Linking Destination Attributes and Shopping Experience", Journal of Travel Research, 52:1, 29-41. DOI : 10.1177/0047287512457263

Yüksel, A., \& Yüksel, F. .(2008), “Consumer Satisfaction Theories: A Critical Review”. Tourist Satisfaction And Complaining Behavior: Measurement And Management Issues In The Tourism And Hospitality Industry, $65-88$.

Yusoff, Zien and Ong, Chuan Huat, (2015), "Influence Of Brand Experience And Personality On Loyalty Dimensions: Evidence From Successful Malaysian SME Brands”, International Journal of Business and Commerce, $4: 7$. 